\title{
Metabolic, Hormonal, and Vascular Changes after Synthetic Oestrogen Therapy in Oophorectomized Women
}

\author{
S. GOW, I. MACGILLIVRAY
}

British Medical fournal, 1971, 2, 73-77

\section{Summary}

Mestranol, the three-methyl ether form of ethinyloestradiol and one of the two oestrogens used in oral contraceptive steroids, was administered in a dose of $0.02 \mathrm{mg}$ daily for 120 days to 25 oophorectomized women.

Urinary oestriol and pregnanediol excretions were unaffected by the mestranol treatment but there was a shift of the maturation index of the vaginal smear to the right, indicating a correction of the pretreatment oestrogen deficiency. No significant change in the blood pressure or electrocardiograph recordings occurred during this relatively short period of administration. A significant rise in the serum protein-bound iodine, which might be regarded as an undesirable effect of mestranol on a long-term basis, occurred. Hepatic function as measured by bromsulphthalein was not impaired by the treatment. Mestranol had no effect on the total body water or on the total exchangeable potassium of the women. Its two most serious adverse effects were impairment of glucose tolerance and a high incidence $(16 \%)$ of venous thromboembolic disease.

The gravity of the adverse effects far outweighs any beneficial ones and precludes the use of mestranol alone for longterm hormone replacement therapy in postmenopausal women.

\section{Introduction}

In the past 20 years an improved understanding of the endocrinological changes occurring at the menopause and their relationship to certain pathological conditions has resulted in the recommendation by several workers (Wilson and Wilson, 1963; Greenblatt, 1965; McEwen, 1965) that long-term hormone replacement therapy should be administered to oestrogen-deficient postmenopausal women.

Though many changes occurring after the menopause are due to oestrogen deficiency, others are due to an unrelated ageing process. The differentiation between the two is not clear and, indeed, in some respects they may be interdependent. This applies to the metabolic and vascular changes which in some instances may be aggravated rather than improved by hormone therapy. There is therefore a need for short-term and long-term controlled clinical trials to assess the benefits and risks involved in administering hormone therapy to postmenopausal women.

We have studied the effects of mestranol on the endocrine status, glucose tolerance, cardiovascular system, serum proteinbound iodine, liver function, and body composition in a group of such women.

\footnotetext{
Department of Obstetrics and Gynaecology, University of Aberdeen Aberdeen AB9 2ZD

S. GOW, M.D., Research Assistant

I. MAcGillivRAY, M.D., F.R.C.o.G., Regius Professor
}

\section{Subjects and Methods}

The volunteer subjects were women who had undergone a hysterectomy and bilateral salpingo-oophorectomy for benign conditions during their premenopausal years. They were healthy women with no known medical disease and they had not received any hormone therapy in the previous 12 months.

Initially 25 women were included in the trial but four of these developed venous thromboembolic complications which necessitated discontinuing the mestranol. Results before starting and at the end of treatment with mestranol $0.02 \mathrm{mg}$ daily for 120 days are therefore available for 21 women. Their mean age was 53.8 (range 46 to 62 ) years and they were at a mean of 8.9 (range 7 to 11 ) years from their artificial menopause.

\section{OUTPATIENT TESTS}

Intravenous Glucose Tolerance Test.-The patient reported to the ward at 9 a.m. in a fasting state. A standard dose of $50 \mathrm{ml}$ of $50 \%$ dextrose was injected intravenously. Blood sugars were measured on the Technicon AutoAnalyzer by the potassium ferricyanide reduction method (Hoffman, 1937) and the results were expressed as the increment index (Duncan, 1956).

A 48-hour Urine Collection for Estimation of Urinary Oestrone and Pregnanediol.-The method for oestrone assay was that of Brown (1955) as modified by Shearman (1964). The method for pregnanediol assay was that of Klopper, Michie, and Brown (1955) with gas chromatography replacing the sulphuric acid end-point.

\section{INPATIENT TESTS}

On the day after completion of the 48-hour urine collection the patient was admitted to a gynaecological ward for 36 hours. She was weighed and measured and had the following investigations:

Vaginal smear for Cytohormonal Evaluation.-The smear was taken with an Ayre's spatula from the upper third of the lateral vaginal wall, immersed in a fixative, and stained by the Papanicolaou technique. It was then examined under a microscope, four or five fields of 200 cells being counted in order to obtain the maturation index.

Blood Pressure.-Supine and erect blood pressure recordings were made.

Serum Protein-bound Iodine.-Estimations were made by automatic digestion on the Technicon AutoAnalyzer (Riley and Gochman, 1964).

Bromsulphthalein Dye Test.- A standard dose of $5 \mathrm{mg}$ of the dye per $\mathrm{kg}$ body weight was injected intravenously and the percentage bromsulphthalein retained at 25 and 45 minutes was measured on the S.P.600 Unicam Spectrophotometer at $540 \mathrm{~m} \mu$ wavelength, a blue filter being used.

Total Body Water and Total Exchangeable Potassium.-These were measured simultaneously by the isotope dilution technique, tritium and radiopotassium $\left({ }^{42} \mathrm{~K}\right)$ being used as tracers. All measurements were done on urine samples, the ${ }^{3} \mathrm{H}$ being counted on the Packard Tricarb Liquid Scintillation Spectrometer and the ${ }^{42} \mathrm{~K}$ on the Tracerlab Gamma Guard 150. 
Results

\section{INTRAVENOUS GLUCOSE TOLERANCE TEST}

Twenty women had an intravenous glucose tolerance test performed (Table I). Before treatment four of them were found to have impaired glucose tolerance, three in the probable diabetic range (increment index 2.46-2.97) and one in the diabetic range (increment index $<2.46$ ). The incidence of impaired glucose tolerance was higher $(27.3 \%)$ in those already predisposed to the development of diabetes by reason of obesity or previous obstetric history than in the non-predisposed woman $(11 \cdot 1 \%)$. The group mean increment index was $4 \cdot 15 \pm 0.301$ S.E.

TABLE I-Increment Index and Weight Changes in 20 Women before and at End of Mestranol Therapy

\begin{tabular}{|c|c|c|c|c|c|c|c|}
\hline \multirow{2}{*}{$\begin{array}{l}\text { Sub- } \\
\text { ject } \\
\text { No. }\end{array}$} & \multirow{2}{*}{ Age } & \multirow{2}{*}{ Parity } & \multirow{2}{*}{$\underset{(\mathrm{cm})}{\text { Height }}$} & \multicolumn{2}{|c|}{ Weight (kg) } & \multicolumn{2}{|c|}{ Increment Index* } \\
\hline & & & & $\begin{array}{l}\text { Before } \\
\text { Treat- } \\
\text { ment }\end{array}$ & $\begin{array}{l}\text { At End of } \\
\text { Treat- } \\
\text { ment }\end{array}$ & $\begin{array}{l}\text { Before } \\
\text { Treat- } \\
\text { ment }\end{array}$ & $\begin{array}{l}\text { At End of } \\
\text { Treat- } \\
\text { ment }\end{array}$ \\
\hline $\begin{array}{r}1 \\
2 \\
3 \\
4 \\
5 \\
6 \\
7 \\
9 \\
10 \\
11 \\
12 \\
13 \\
14 \\
15 \\
16 \\
17 \\
18 \\
19 \\
20 \\
21\end{array}$ & $\begin{array}{l}56 \\
55 \\
64 \\
56 \\
55 \\
48 \\
53 \\
60 \\
60 \\
49 \\
52 \\
51 \\
53 \\
46 \\
51 \\
52 \\
58 \\
49 \\
62 \\
49\end{array}$ & $\begin{array}{l}2+0 \\
0+0 \\
1+0 \\
2+0 \\
5+0 \\
1+0 \\
0+0 \\
2+0 \\
3+0 \\
2+0 \\
4+2 \\
9+0 \\
2+0 \\
1+0 \\
1+0 \\
3+0 \\
5+0 \\
3+0 \\
3+2 \\
1+0\end{array}$ & $\begin{array}{l}144 \\
149 \\
157 \cdot 5 \\
159 \cdot 5 \\
145 \cdot 5 \\
168 \\
162 \\
151 \cdot 5 \\
151 \\
163 \\
153 \\
154 \\
152 \\
158 \\
163 \\
160 \\
160 \\
146 \\
157 \\
165\end{array}$ & $\begin{array}{l}49 \cdot 7 \\
52.6 \\
67.2 \\
91.5 \\
65.6 \\
63.25 \\
68.9 \\
70 \cdot 2 \\
50 \cdot 75 \\
69 \cdot 3 \\
56.5 \\
70 \cdot 0 \\
63.65 \\
54.45 \\
92.45 \\
79.3 \\
71 \cdot 2 \\
48 \\
59 \cdot 25 \\
55.65\end{array}$ & $\begin{array}{l}48 \cdot 3 \\
53 \cdot 9 \\
66 \\
91 \cdot 85 \\
65 \cdot 1 \\
62 \cdot 75 \\
69 \\
64 \cdot 5 \\
49 \cdot 9 \\
71 \cdot 75 \\
57 \cdot 8 \\
64 \cdot 25 \\
59 \cdot 2 \\
56 \cdot 5 \\
95 \\
79 \\
66 \cdot 95 \\
48 \cdot 45 \\
61 \cdot 4 \\
54 \cdot 7\end{array}$ & $\begin{array}{l}4.33 \\
3.47 \\
2.67 \\
4.62 \\
4.08 \\
4.62 \\
2.76 \\
1.98 \\
5.78 \\
3.39 \\
5.12 \\
2.48 \\
6.93 \\
6.93 \\
4.95 \\
3.96 \\
4.62 \\
3.65 \\
3.65 \\
3.08\end{array}$ & $\begin{array}{l}2 \cdot 1 \\
2.24 \\
2.24 \\
2.04 \\
2.76 \\
1.62 \\
4.33 \\
1.69 \\
4.33 \\
3.22 \\
5.37 \\
1.87 \\
3.08 \\
5.37 \\
2.17 \\
3.01 \\
3.15 \\
2.17 \\
2.04 \\
2.04\end{array}$ \\
\hline $\begin{array}{l}\text { Mean } \\
\text { Standa } \\
\text { Standa }\end{array}$ & $\begin{array}{l}53.9 \\
\text { deviation } \\
\text { error }\end{array}$ & $\begin{array}{l}2 \cdot 7 \\
\ldots\end{array}$ & $\because$ & $\begin{array}{c}64.9 \\
+12.62 \\
\pm 2.82\end{array}$ & $\begin{array}{c}64.3 \\
+12.71 \\
\pm 2.84\end{array}$ & $\begin{array}{r}4.15 \\
+1.35 \\
\pm 0.301\end{array}$ & $\begin{array}{r}2.84 \\
+1.15 \\
\pm 0.257\end{array}$ \\
\hline
\end{tabular}

* Figures in italic are outside normal range.

At the end of mestranol treatment 12 of the 20 women had impaired glucose tolerance, one in the probable diabetic range and 11 in the diabetic range. This was not accompanied by any significant weight change and appeared to be independent of whether the women were predisposed to the development of diabetes (incidence $63.6 \%$ ) or not (incidence $55.6 \%$ ). The increment index had decreased in 18 of the 20 women, the mean for the group now being $2.84+0.257$ S.E.

The mean blood glucose values on treatment were higher than the control values, and this difference was statistically significant at 20, 30, 40, 50, and 60 minutes (see Chart).

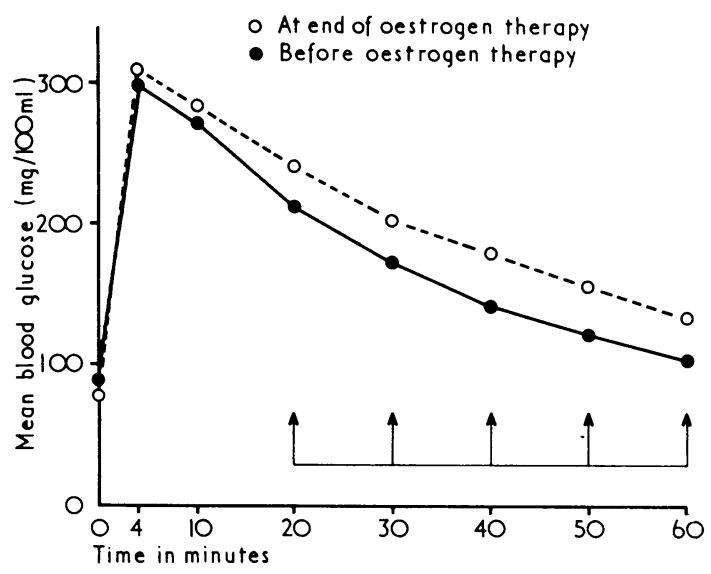

Mean blood glucose values in 19 patients. Arrows indicate statistically significant differences.
A third intravenous glucose tolerance test was done in 14 of the women four months after the mestranol therapy had been stopped (Table II). The increment index had reverted to the normal range in all except two of the women, one (Subject 9) had had an increment index in the diabetic range throughout testing and the other (Subject 4), who originally had a normal increment index, deteriorated on mestranol and failed to revert to normal after the mestranol was stopped. She was $30 \mathrm{~kg}$ above her ideal weight.

TABLE $\mathrm{II}$-Increment Index in 14 Oophorectomized Women before, during, and after Treatment with Mestranol

\begin{tabular}{|c|c|c|c|}
\hline \multirow{2}{*}{$\begin{array}{l}\text { Subject } \\
\text { No. }\end{array}$} & \multicolumn{3}{|c|}{ Increment Index } \\
\hline & $\begin{array}{l}\text { Before } \\
\text { Treatment }\end{array}$ & $\underset{\text { Treatment* }}{\text { During }}$ & $\begin{array}{c}\text { After } \\
\text { Treatment }+\end{array}$ \\
\hline $\begin{array}{r}1 \\
2 \\
3 \\
4 \\
5 \\
6 \\
7 \\
9 \\
13 \\
16 \\
17 \\
19 \\
20 \\
21\end{array}$ & $\begin{array}{l}4.33 \\
3.47 \\
2.67 \\
4.62 \\
4.08 \\
4.62 \\
2.76 \\
1.98 \\
2.48 \\
4.95 \\
3.96 \\
3.65 \\
3.65 \\
3.08\end{array}$ & $\begin{array}{l}2 \cdot 1 \\
2.24 \\
2.24 \\
2.04 \\
2.76 \\
1.62 \\
4.33 \\
1.69 \\
1.87 \\
2.17 \\
3.01 \\
2.17 \\
2.04 \\
2.04\end{array}$ & $\begin{array}{l}4.62 \\
3.15 \\
3.47 \\
2.43 \\
3.15 \\
6.3 \\
4.01 \\
1.82 \\
4.62 \\
5.12 \\
5.37 \\
3.55 \\
4.08 \\
4.08\end{array}$ \\
\hline $\begin{array}{l}\text { Mean } \\
\text { Standard } \\
\text { deviation } \\
\text { Standard } \\
\text { error }\end{array}$ & $\begin{array}{l}3.59 \\
\pm 0.9 \\
\pm 0.241\end{array}$ & $\begin{aligned} & 2.31 \\
\pm & 0.2 \\
\pm & 0.054\end{aligned}$ & $\begin{array}{r}3.98 \\
\pm 1.19 \\
\pm 0.318\end{array}$ \\
\hline
\end{tabular}

* Done during the last week of mestranol therapy.

$\dagger$ Done four months after end of therapy.

\section{URINARY OESTRONE AND PREGNANEDIOL}

This was measured in 21 women (Table III). Before treatment the mean urinary oestrone was $2.31+0.33 \mu \mathrm{g} / 24$ hours and the mean urinary pregnanediol was $0 . \overline{2} 54 \pm 0.06 \mathrm{mg} / 24$ hours. These values are within the normal range for this age group. Mestranol had no effect on the excretion of oestrone or pregnanediol, the mean urinary oestrone being $2.84+0.36 \mu \mathrm{g} / 24$ hours and the mean pregnanediol $0 \cdot 19 \pm 0.04 \mathrm{mg} / 24$ hours at the end of treatment.

TABLE III-Urinary Oestrone and Pregnanediol in 21 Oophorectomized Women before Starting and at End of Mestranol Therapy

\begin{tabular}{|c|c|c|c|c|c|}
\hline \multirow{2}{*}{$\begin{array}{c}\text { Mean } \\
\text { Age }\end{array}$} & \multirow{2}{*}{$\begin{array}{l}\text { Mean No. } \\
\text { of Years } \\
\text { since } \\
\text { Menopause }\end{array}$} & \multicolumn{2}{|c|}{$\begin{array}{c}\text { Urinary Oestrone } \\
(\mu \mathrm{g} / 24 \mathrm{hr}) \\
\text { Mean } \pm \text { S.D. }( \pm \text { S.E. })\end{array}$} & \multicolumn{2}{|c|}{$\begin{array}{l}\text { Urinary Pregnanediol } \\
(\mathrm{mg} / 24 \mathrm{hr}) \\
\text { Mean } \pm \mathrm{S} . \mathrm{D} .( \pm \text { S.E. })\end{array}$} \\
\hline & & $\begin{array}{c}\text { Before } \\
\text { Treatment }\end{array}$ & $\begin{array}{l}\text { At End of } \\
\text { Treatment }\end{array}$ & $\begin{array}{c}\text { Before } \\
\text { Treatment }\end{array}$ & $\begin{array}{l}\text { At End of } \\
\text { Treatment }\end{array}$ \\
\hline 53.8 & 8.9 & $\begin{array}{c}2.31 \pm 1.5 \\
( \pm 0.33)\end{array}$ & $\begin{array}{c}2 \cdot 84 \pm 1 \cdot 6 \\
( \pm 0 \cdot 36)\end{array}$ & $\begin{array}{c}0.254 \pm 0.213 \\
( \pm 0.06)\end{array}$ & $\begin{array}{c}0.19 \pm 0 \cdot 105 \\
( \pm 0.04)\end{array}$ \\
\hline
\end{tabular}

\section{VAGINAL CYTOLOGY}

From Table IV it can be seen that before treatment the vaginal smears were primarily of an intermediate type, the group mean maturation index being 24:71: 5. An oestrogen value of the smear was derived by allocating basal and parabasal cells 0 poir,, intermediate cells 0.5 point, and superficial cells 1 point (Dovi. 1968). Before treatment the group mean oestrogen value was 4 . A A correlation was found between the urinary oestrone excretion and the oestrogen value of the smear but this was improved with higher values of the latter (correlation coefficient 0.38 when oestrogen value $>43$ ). At the end of treatment the group mean maturation index was $0: 72: 28$ and the group mean oestrogen value $64 \cdot 1$. 
TABLE IV-Maturation Index in 21 Oophorectomized Women before Start of and at the End of Mestranol Therapy

\begin{tabular}{|c|c|c|c|c|c|}
\hline \multirow{2}{*}{$\begin{array}{l}\text { Subject } \\
\text { No. }\end{array}$} & \multirow{2}{*}{$\begin{array}{l}\text { No. of } \\
\text { P.M. } \\
\text { Years }\end{array}$} & \multicolumn{2}{|c|}{ Before Treatment } & \multicolumn{2}{|c|}{ At End of Treatment } \\
\hline & & $\begin{array}{l}\text { Maturation } \\
\text { Index }\end{array}$ & $\begin{array}{l}\text { Oestrogen } \\
\text { Value }\end{array}$ & $\begin{array}{l}\text { Maturation } \\
\text { Index }\end{array}$ & $\begin{array}{c}\text { Oestrogen } \\
\text { Value }\end{array}$ \\
\hline $\begin{aligned} 1 \\
2 \\
3 \\
4 \\
5 \\
6 \\
7 \\
8 \\
9 \\
10 \\
11 \\
12 \\
13 \\
14 \\
15 \\
16 \\
17 \\
18 \\
19 \\
20 \\
21\end{aligned}$ & $\begin{aligned} 11 \\
11 \\
11 \\
11 \\
11 \\
10 \\
9 \\
7 \\
9 \\
9 \\
8 \\
7 \\
7 \\
7 \\
7 \\
10 \\
9 \\
10 \\
8 \\
8 \\
8\end{aligned}$ & $\begin{array}{r}10: 90: 0 \\
24: 75: 1 \\
73: 27: 0 \\
2: 96: 2 \\
44: 54: 2 \\
1: 96: 3 \\
18: 76: 6 \\
0: 100: 0 \\
30: 70: 0 \\
0: 88: 12 \\
0: 84: 16 \\
1: 96: 3 \\
12: 86: 2 \\
70: 30: 0 \\
56: 44: 0 \\
0: 52: 48 \\
24: 76: 0 \\
2: 98: 0 \\
16: 84: 0 \\
54: 46: 0 \\
72: 28: 0\end{array}$ & $\begin{array}{l}45 \\
38 \\
14 \\
50 \\
29 \\
51 \\
44 \\
50 \\
35 \\
56 \\
58 \\
51 \\
45 \\
15 \\
22 \\
74 \\
38 \\
49 \\
42 \\
21 \\
14\end{array}$ & $\begin{array}{c}0: 76: 24 \\
0: 82: 18 \\
0: 90: 10 \\
0: 78: 22 \\
0: 84: 16 \\
0: 16: 84 \\
0: 68: 32 \\
0: 66: 34 \\
0: 68: 32 \\
0: 90: 10 \\
0: 52: 48 \\
0: 88: 12 \\
0: 94: 6 \\
0: 76: 23 \\
0: 42: 58 \\
0: 68: 32 \\
0: 80: 20 \\
0: 72: 28 \\
-\end{array}$ & $\begin{array}{l}62 \\
59 \\
55 \\
61 \\
58 \\
92 \\
66 \\
67 \\
66 \\
55 \\
74 \\
56 \\
53 \\
61 \\
79 \\
66 \\
60 \\
64 \\
-\end{array}$ \\
\hline Mean & 8.9 & $24: 71: 5$ & 40 & $0: 72: 28$ & $64 \cdot 1$ \\
\hline
\end{tabular}

\section{CARDIOVASCULAR SYSTEM}

Three of the 21 women were found to be hypertensive but in only one had it developed subsequent to her operation, and she was grossly obese. Mestranol had no consistent effect on the blood pressure. None of the 21 women had E.C.G. changes which could be attributed solely to oestrogen deficiency. Mestranol had no demonstrable effect on the E.C.G. tracings.

Four of the 25 women who had been started on mestranol developed venous complications, three having a deep-vein thrombosis and one a superficial thrombophlebitis. The relevant findings in these four women are given in Table $\mathrm{V}$. Their mean age was 57.3 years and they were at a mean of 8.5 years from their artificial menopause. The mean duration of mestranol treatment was 67.5 days. Predisposing factors to the development of venous thromboembolic disease existed in all four. Subject 22 had had multiple ligations of varicose veins of both lower legs 13 years previously but had had no recurrence since then; she was also hypertensive. Subject 23 was overweight and hypertensive. Subject 24 was found to have impaired glucose tolerance. Subject 25 was overweight. For comparison, in the 21 women who completed the mestranol course uneventfully, the incidence of obesity and impaired glucose tolerance was exactly the same as in these four. The incidence of hypertension was very much less, however, and none of the 21 had a history of previous venous surgery.

TABLE V-Data on Four Patients who Developed Venous Complications while on Mestranol Therapy

\begin{tabular}{|c|c|c|c|c|c|c|}
\hline \multicolumn{3}{|c|}{ Subject No.: } & \multirow{2}{*}{$\begin{array}{c}22 \\
\text { D.V.T. } \\
56 \\
9 \\
50 \\
+\end{array}$} & \multirow{2}{*}{$\begin{array}{c}23 \\
\text { D.V.T. } \\
55 \\
7 \\
80 \\
-\end{array}$} & \multirow{2}{*}{$\begin{array}{c}24 \\
\text { D.V.T. } \\
55 \\
7 \\
70 \\
-\end{array}$} & \multirow{2}{*}{$\begin{array}{l}25 \\
\text { S.T. } \\
63 \\
11 \\
70 \\
-\end{array}$} \\
\hline $\begin{array}{l}\text { Complication } \\
\text { Age } \\
\text { Years postmenop } \\
\text { Duration of thera } \\
\text { Previous venous }\end{array}$ & $\begin{array}{l}\cdots \quad \ldots \\
\because \\
\text { pausal } \quad \because \\
\text { apy (days) } \\
\text { episode }\end{array}$ & $\begin{array}{l}\ldots \\
\ldots \\
\ldots \\
\ldots\end{array}$ & & & & \\
\hline $\begin{array}{l}\text { Smoker ... } \\
\text { Blood group }\end{array}$ & $\begin{array}{ll}. & \end{array}$ & $\cdots$ & $\overline{0+}$ & $\overline{B+}$ & $0=$ & $A \pm$ \\
\hline $\begin{array}{l}\text { Blood group } \\
\text { Overweight }\end{array}$ & $\because$ & $\because$ & $\underline{0+}$ & Bt & $=$ & + \\
\hline Impaired glucose & e tolerance & .. & - & - & + & - \\
\hline Hypertension & . $\quad$. & .. & + & + & - & - \\
\hline
\end{tabular}

D.V.T. = Deep-vein thrombosis. S.T. = Superficial thrombophlebitis.
No blood group relationship with the occurrence of venous thromboembolic disease was found in the group under study.

\section{SERUM PROTEIN-BOUND IODINE}

Before treatment the group mean serum P.B.I. was $5 \cdot 9 \pm 2 \cdot 8$ $\mu \mathrm{g} / 100 \mathrm{ml}$. At the end of treatment it was $9 \cdot 1 \pm 0.38 \mu \mathrm{g} / 100 \mathrm{ml}$. The mean change from the baseline was $3.2+0.38 \mu \mathrm{g} / 100 \mathrm{ml}$, and this was statistically significant $(P>0.00 \overline{1})$.

\section{BROMSULPHTHALEIN DYE TEST}

In all 21 women the percentage BSP retained at 25 minutes was within normal limits before and at the end of the mestranol course (Table VI). Before treatment the percentage BSP retained at 45 minutes was slightly raised in two women (Subjects 3 and 9) at 8.5 and $7.5 \%$ respectively. By the end of treatment these two "abnormals" had reverted to normal but a further two women (Subjects 7 and 21) had developed slightly raised BSP retentions, 7.5 and $7 \%$ respectively. If the effect of age on liver function is taken into account (Freston and Englert, 1967) these "abnormals" are of doubtful significance and there is no evidence that the mestranol had any adverse effect on liver function.

TABLE VI-Percentage BSP Retained at 25 and 45 Minutes in 21 Women before Start of and at the End of Mestranol Therapy.

\begin{tabular}{|c|c|c|c|c|c|}
\hline \multirow{3}{*}{$\begin{array}{c}\text { Subject } \\
\text { No. }\end{array}$} & \multirow{3}{*}{$\begin{array}{c}\text { Weight/ } \\
\text { Height }\end{array}$} & \multicolumn{4}{|c|}{ BSP Retained (\%)* } \\
\hline & & \multicolumn{2}{|c|}{ Before Treatment } & \multicolumn{2}{|c|}{ At End of Treatment } \\
\hline & & $25 \mathrm{~min}$ & $45 \mathrm{~min}$ & $25 \mathrm{~min}$ & $45 \mathrm{~min}$ \\
\hline $\begin{array}{r}1 \\
2 \\
3 \\
4 \\
5 \\
6 \\
7 \\
8 \\
9 \\
10 \\
11 \\
12 \\
13 \\
14 \\
15 \\
16 \\
17 \\
18 \\
19 \\
20 \\
21\end{array}$ & $\begin{array}{l}0.345 \\
0.353 \\
0.427 \\
0.573 \\
0.451 \\
0.376 \\
0.425 \\
0.347 \\
0.463 \\
0.336 \\
0.425 \\
0.369 \\
0.454 \\
0.412 \\
0.345 \\
0.567 \\
0.495 \\
0.445 \\
0.328 \\
0.377 \\
0.337\end{array}$ & $\begin{array}{r}6 \cdot 0 \\
8 \cdot 0 \\
12.5 \\
5 \cdot 0 \\
3.5 \\
0 \cdot 2 \\
7 \cdot 5 \\
4.5 \\
8 \\
5 \cdot 0 \\
3 \cdot 0 \\
7 \cdot 5 \\
4.5 \\
0 \\
2 \\
3.5 \\
5 \cdot 0 \\
5 \cdot 0 \\
2 \cdot 0 \\
6 \cdot 0 \\
5 \cdot 0\end{array}$ & $\begin{array}{l}2.0 \\
1.5 \\
8.5 \\
1.0 \\
1.0 \\
0 \\
5.0 \\
2.5 \\
7.5 \\
0 \\
1.5 \\
1.5 \\
0 \\
0 \\
0 \\
1.5 \\
1.0 \\
2.0 \\
1.5 \\
1.5 \\
2.0\end{array}$ & $\begin{array}{r}2.0 \\
2.5 \\
12.0 \\
1.5 \\
4.5 \\
4.0 \\
12.5 \\
2.0 \\
7.5 \\
2.5 \\
= \\
5.0 \\
8.5 \\
5.5 \\
5.0 \\
7.5 \\
2.0 \\
5.0 \\
2.5 \\
10.0\end{array}$ & $\begin{array}{l}0 \\
0 \\
4.5 \\
0 \\
0 \\
0.5 \\
7.5 \\
0 \\
5.0 \\
0 \\
= \\
= \\
0.5 \\
4.5 \\
4.5 \\
2.0 \\
2.5 \\
0 \\
0 \\
0 \\
7.0\end{array}$ \\
\hline
\end{tabular}

*Figures in italic are outside normal range.

\section{TOTAL BODY WATER AND TOTAL $\mathrm{K}^{\mathrm{e}}$}

Total body water was measured in 18 women. Before treatment the group mean was $29.1+1.06$ litres. This represented a mean of $46.8 \%$ body weight, which is within the normal range for this age group. At the end of treatment the group mean total body water was $27.9 \pm 1.21$ litres The mean change in total body water was $-1.22 \pm 0.54$ litres which is within the normal range of variation for the method used. The accompanying weight change was $-0.25+0.53 \mathrm{~kg}$ (Table VII). The mestranol had therefore no effect on the total body water estimations.

\begin{tabular}{|c|c|c|c|c|c|c|c|}
\hline \multirow{2}{*}{$\underset{\text { Age }}{\text { Mean }}$} & \multirow{2}{*}{$\begin{array}{l}\text { Mean No. of } \\
\text { Years since } \\
\text { Menopause }\end{array}$} & \multicolumn{2}{|c|}{$\begin{array}{c}\text { Weight (kg) } \\
\text { Mean } \pm \text { S.D. }( \pm \text { S.E. })\end{array}$} & \multicolumn{2}{|c|}{$\begin{array}{l}\text { Total Body Water (l) } \\
\text { Mean } \pm \text { S.D. }( \pm \text { S.E. })\end{array}$} & \multirow{2}{*}{$\begin{array}{l}\text { Mean Change in } \\
\text { Weight (kg) } \\
\pm \text { S.D. }( \pm \text { S.E. })\end{array}$} & \multirow{2}{*}{$\begin{array}{l}\text { Mean Change in } \\
\text { T.B.W. (I) } \\
\pm \text { S.D. }( \pm \text { S.E. })\end{array}$} \\
\hline & & Before Treatment & At End of Treatment & Before Treatment & At End of Treatment & & \\
\hline 53.9 & $9 \cdot 1$ & $64 \cdot 2 \pm 13 \cdot 39( \pm 3 \cdot 17)$ & $63.9 \pm 13.84( \pm 3.26)$ & $29.1 \pm 4.51( \pm 1.06)$ & $27 \cdot 9 \pm 5 \cdot 12( \pm 1 \cdot 21)$ & $-0.25 \pm 2.25( \pm 0.53)$ & $-1.22 \pm 2.29( \pm 0.54)$ \\
\hline
\end{tabular}


Total exchangeable potassium $\left(\mathrm{K}^{\mathrm{e}}\right)$ was measured in 19 women (Table VIII). Before treatment the mean was 2,186 \pm $69.2 \mathrm{mEq}$. $\mathrm{K}^{\mathrm{e}}$ was expressed in relation to body height, body weight, and lean body mass (derived from Pace-Rathbun formula using total body water). At the end of treatment the group mean $\mathrm{K}^{\mathrm{e}}$ was $2,315 \pm 146 \cdot 25 \mathrm{mEq}$. Three women had a significant increase, three a significant decrease, and 13 had no change in $\mathrm{K}^{\mathrm{e}}$ on mestranol.

TABLE VIII-Absolute Values of Total Exchangeable Potassium (Ke) Before Start of and at the End of Mestranol Therapy

\begin{tabular}{|c|c|c|c|c|c|c|}
\hline \multirow{2}{*}{$\begin{array}{c}\text { Subject } \\
\text { No. }\end{array}$} & \multirow{2}{*}{$\begin{array}{l}\text { Weight/ } \\
\text { Height }\end{array}$} & \multicolumn{5}{|c|}{$\mathrm{K}(\mathrm{mEq})$} \\
\hline & & $\begin{array}{c}\text { Before } \\
\text { Treatment }\end{array}$ & $\begin{array}{l}\text { At End of } \\
\text { Treatment }\end{array}$ & Mean & Deviation & $\begin{array}{l}\text { Deviation } \\
\% \text { of Mean }\end{array}$ \\
\hline $\begin{array}{r}1 \\
3 \\
4 \\
5 \\
6 \\
7 \\
9 \\
10 \\
11 \\
12 \\
13 \\
14 \\
15 \\
16 \\
17 \\
18 \\
19 \\
20 \\
21\end{array}$ & $\begin{array}{l}0.345 \\
0.427 \\
0.573 \\
0.451 \\
0.376 \\
0.425 \\
0.463 \\
0.336 \\
0.425 \\
0.369 \\
0.454 \\
0.412 \\
0.345 \\
0.567 \\
0.495 \\
0.445 \\
0.328 \\
0.377 \\
0.347\end{array}$ & $\begin{array}{l}1,639 \\
2,025 \\
2,132 \\
2,307 \\
2,233 \\
2,627 \\
2,308 \\
2,187 \\
2,180 \\
2,004 \\
2,153 \\
2,301 \\
2,461 \\
2,998 \\
2,228 \\
2,091 \\
1,841 \\
2,010 \\
1,810\end{array}$ & $\begin{array}{l}2,430 \\
2,284 \\
2,424 \\
1,833 \\
2,362 \\
3,823 \\
2,225 \\
2,045 \\
3,943 \\
1,612 \\
2,077 \\
1,973 \\
2,261 \\
2,955 \\
2,213 \\
2,096 \\
1,510 \\
2,009 \\
1,920\end{array}$ & $\begin{array}{l}2,034 \\
2,154 \\
2,278 \\
2,070 \\
2,297 \\
3,225 \\
2,266 \\
2,116 \\
3,061 \\
1,808 \\
2,115 \\
2,137 \\
2,361 \\
2,976 \\
2,221 \\
2,093 \\
1,675 \\
2,009 \cdot 5 \\
1,865\end{array}$ & $\begin{array}{l}+395 \\
+129 \\
+146 \\
-237 \\
+64 \\
+598 \\
-41 \\
-71 \\
+881 \\
+196 \\
-38 \\
-164 \\
-100 \\
=22 \\
+\quad 7 \\
+16 \\
-165 \\
+\quad 0 \cdot 5 \\
+55\end{array}$ & $\begin{array}{r}14.4 \\
5.9 \\
6.4 \\
11.3 \\
2.8 \\
18.5 \\
1.8 \\
3.4 \\
28.8 \\
10.3 \\
1.8 \\
7.7 \\
4.2 \\
0.75 \\
0.31 \\
0.09 \\
9.8 \\
0.02 \\
2.9\end{array}$ \\
\hline $\begin{array}{l}\text { Mean } \\
\text { Standard } \\
\text { deviation } \\
\text { Standard } \\
\text { error }\end{array}$ & 0.419 & $\begin{array}{c}2,186 \\
\pm 301 \cdot 74 \\
\pm 69 \cdot 21\end{array}$ & $\begin{array}{c}2,315 \\
\pm 637.65 \\
\pm 146.25\end{array}$ & $\begin{array}{l}2,250 \\
\pm 411.39 \\
\pm 94.36\end{array}$ & $\begin{array}{l}+64 \\
\pm 253.17 \\
\pm 58.07\end{array}$ & $\begin{array}{l}2.8 \\
\pm 7.58 \\
\pm 1.74\end{array}$ \\
\hline
\end{tabular}

\section{Discussion}

The adverse effects of hormone therapy in younger women have been well documented. The oestrogen component of oral contraceptive steroids has been implicated in causing hypertension (Laragh, Sealey, Ledingham, and Newton, 1967), impairment of glueose toterañce (Spellacy and Carlson, 1966; Javier, Gershberg, and Hulse, 1968), alteration in bloodclotting factors (Nilsson and Kullander, 1967), venous thromboembolic disease (Inman, Vessey, Westerholm, and Engelund, 1970), impairment of liver function (Eisalo, Heino, and Räsänen, 1968), and several other undesirable effects.

By reason of their age, postmenopausal women are already predisposed to the development of many of these conditions. Glucose tolerance decreases with age. The incidence of thromboembolic disease increases with age and also in the presence of predisposing factors such as obesity, hypertension, and diabetes, which in turn will be more prevalent in older age groups. Hepatic function deteriorates with age and obesity.

In theory, then, the adverse effects of synthetic oestrogens seen in younger women may be seen more often and be of a more serious nature in older women. This has been borne out by the present study. The incidence of impaired glucose tolerance increased from 20 to $60 \%$ on mestranol treatment. Several authors (Javier et al., 1968; Goldman and Ovadia, 1969) have shown that this adverse effect of hormone therapy in younger women commonly occurs in those already predisposed to the develpoment of diabetes. In the present study the mestranol effect was independent of whether the women were predisposed or not. This suggests either that mestranol in the dose used had a peculiarly adverse effect on glucose tolerance or that all these women could be regarded as being predisposed to diabetes by reason of their age. Whether the continued administration of oestrogen would result in overt diabetes is still uncertain. The fact that one woman out of 12 failed to revert to normal after discontinuance of the drug merits further study.
The high incidence of thromboembolic disease (16\%) found in this study is also a cause for concern. The dose of oestrogen used was well within the safe limit advised by the Committee on Safety of Drugs for use in younger women. Again, it may be due to a peculiar effect of mestranol. Alternatively, it may be that the addition of a progestogen would have opposed this adverse effect. The latter theory is supported by the lack of reports of venous complications in large series where oestrogen/progestogen combinations have been administered to postmenopausal women (Bedford, 1967; Taylor and Rizkallah, 1967). Eisalo et al. (1968) reported four cases of "severe thromboembolic disease" in 39 postmenopausal women being treated with various hormone preparations but they do not specify which particular hormone therapy was implicated. If the high incidence of venous complications found in the present study is a reflection of the possible course of events in the general population, then this poses a serious problem regarding the ethics of administering oestrogens to postmenopausal women. Though these two adverse effects are of such a serious nature as to contraindicate the use of mestranol for long-term hormone replacement therapy, it is worth while mentioning other effects observed in this study.

Mestranol in the small dose used caused the desired shift of the maturation index to the right. It did not cause any impairment of liver function, which is at variance with the reports of other workers (Eisalo, Järvinen, and Luukkainen, 1964; Eisalo et al., 1968). It did not promote water retention or weight gain in the women. The absence of any effect of mestranol on the blood pressure or E.C.G. recordings can probably be explained by the low dose and short duration of therapy. The decrease in exchangeable potassium which is known to occur with advancing years was thought to be associated with the menopause (MacGillivray, Buchanan, and Billewicz, 1960), but in the present study mestranol failed to reverse it. Mestranol did cause a significant rise in the serum P.B.I., an effect which has been recognized for many years (Alexander and Marmorston, 1961). The significance of this on a longterm basis is uncertain.

This study serves to highlight the dangers of indiscriminate administration of hormone therapy to postmenopausal women on the currently popular "eternal youth" basis.

Osteoporosis and coronary artery disease are features of the postmenopausal woman and good evidence exists that they can be prevented by adequate hormone replacement therapy (Wallach and Henneman, 1959; Higano, Robinson, and Cohen, 1963; Parrish, Carr, Hall, and King, 1967). This is a recognized medical fact. What remains to be determined is which hormone therapy can be safely prescribed in this age group.

This study was supported by a grant from G. D. Searle and Co. Ltd., who also provided the mestranol, which we gratefully acknowledge. We thank Dr. A. Klopper and the laboratory staff of the clinical research unit of the department of obstetrics and gynaecology; Mr. J. A. R. McIntosh and Mrs. H. Sluyter, of the department of medical physics; Dr. J. E. Macgregor and Mr. R. Horne, of the department of pathology; and Dr. B. Hickson, medical registrar, for their advice and technical help during the study. We also thank the nursing staff of ward 7, Aberdeen City Hospital, for their co-operation.

\section{References}

Alexander, R. W., and Marmorston, J. (1961). Fournal of Clinical Endocrinology and Metabolism, 21, 243.

Bedford, J. R. D. (1967). Postgraduate Medical fournal, Dec. Suppl., p. 51 .

Brown, J. B. (1955). Biochemical fournal, 60, 185.

Dove, G. (1968). Clinical Trials fournal, Jan., p. 91.

Duncan, L. J. P. (1956). Quarterly fournal of Experimental Physiology, $41,85$.

Eisalo, A., Heino, A., and Räsänen, V. (1968). Acta Obstetricia et Gynecologica Scandinavica, 47, 58.

Eisalo, A., Järvinen, P. A., and Luukkainen, T. (1964). British Medical fournal, 2, 426. 
Freston, J. W., and Englert, E. (1967). Clinical Science, 33, 301.

Goldman, J. A., and Ovadia, J. L. (1969). American fournal of Obstetrics and Gynecology, 103, 172 .

Greenblatt, R. (1965). New England fournal of Medicine, 272, 305.

Higano, N., Robinson, R. W., and Cohen, W. D. (1963). New England Fournal of Medicine, 268, 1123.

Hoffman, W. S. (1937). Fournal of Biological Chemistry, 120, 51.

Inman, W. H. W., Vessey, M. P., Westerholm, B., and Engelund, A. (1970). British Medical fournal, 2, 203.

Javier, Z., Gershberg, H., and Hulse, M. (1968). Metabolism, 17, 443. lopper, A., Michie, E. A., and Brown, J. B. (1955). Fournal of Endocrinology, 12, 209.

Laragh, J. H., Sealey, J. E., Ledingham, J. G. G., and Newton, M. A. (1967). Fournal of the American Medical Association, 201, 918.

McEwen, D. C. (1965). Canadian Medical Association fournal, 92, 962.
MacGillivray, I., Buchanan, T. J., and Billewicz, W. Z. (1960). Clinical Science, 19, 17

Nilsson, I. M., and Kullander, S. (1967). Acta Obstetricia et Gynecologica Scandinavica, 46, 286

Parrish, H. M., Carr, C. A., Hall, D. G., and King, T. M. (1967). American fournal of Obstetrcis and Gynecology, 99, 155.

Riley, M., and Gochman, N. (1964). Technicon Symposium.

Shearman, R. P. (1964). M.D. Thesis, University of Sydney, Australia.

Spellacy, W. N., and Carlson. K. L. (1966). American fournal of Obstetrics and Gynecology, 95, 474 .

Taylor, M. L., and Rizkallah, T. H. (1967). American fournal of Obstetrics and Gynecology, 97, 460 .

Wallach, S., and Henneman, P. H. (1959). Fournal of the American Medical Association, 171, 1637.

Wilson, R. A.s and Wilson, T. (1963). Fournal of the American Geriatrics Society, 11, 347 .

\title{
Migraine: Intelligence, Social Class, and Familial Prevalence
}

\author{
W. E. WATERS
}

British Medical fournal, 1971, 2, 77-81

\section{Summary}

Groups of individuals with headache, unilateral headache, and migraine, and a fourth group who had not had a headache in the previous year, were identified by questionnaire from a random sample of adults in the general population. Intelligence and social class were assessed in about 400 individuals. There was no evidence that individuals with migraine were more intelligent or of higher social class. There was, however, a suggestion that the more intelligent individuals with migraine, and those in social classese I and II, were more likely to consult a doctor for their headaches. This trend might explain the origin of the hypotheses associating migraine with intelligence and with social class.

Random samples of individuals with migraine with headache and without headache in the previous year were the probands for a family study. There were 524 first-degree relatives over 21 years of age who lived in South Wales. Headache histories, obtained "blindly" from over $99 \%$ of these relatives with a standard questionnaire, were classified as migraine, possible migraine, headache, or without headache in the previous year. The prevalence of migraine in the families of the migrainous probands was nearly twice as high as the prevalence in the other families, but this difference was not statistically significant. It is suggested that family history should not be included in the definition of migraine and that heredity is much less important in migraine than is usually supposed.

\section{Introduction}

The extensive literature on migraine mentions many characteristics of the sufferers. Often there is little evidence to support these hypotheses, and in part this is due to the difficulty

M.R.C. Epidemiology Unit (South Wales), Cardiff

W. E. WATERS, M.B. D.I.H., Member of Staff (Present appointment : Senior Lecturer in Clinical Epidemiology and Community Medicine, University of Southampton, Southampton S09 $5 \mathrm{NH}$ ) of obtaining suitable controls for comparison with the migraine groups. It has long been thought that migraine is commoner among the more intelligent, and also in the higher social classes. These views are based on clinical impressions, but such associations can be satisfactorily tested only in representative community samples. The methods used should reduce the possibilities of bias to a minimum. This paper describes an epidemiological study designed to test these hypotheses.

Migraine has long been accepted as a familial condition, and this was stressed by Liveing (1873). Subsequent studies have strengthened this impression-for example, Balyeat and Rinkel (1931), Grimes (1931), Lennox (1941), Leyton (1954), Walker (1959), Selby and Lance (1960), and Childs and Sweetnam (1961). References to a familial tendency are often brief and the method used is uncertain. Some give the percentage of migrainous patients with a "positive family history." Others give detailed family trees, but these may be highly selected. Most published work confirms the tendency of migraine to run in families. Two methodological difficulties, however, may seriously affect this conclusion. One is the problem of defining migraine. Different authors give differing definitions-none completely satisfactory-and many give no definition at all. A definition is especially important as the other weakness of most studies is the possibility of bias. This may occur in the selection of patients with migraine or in the collection of data from their families.

Most published data come from selected series of patients. It is difficult to know how selected they are and hence whether they are typical of all migraine sufferers in the general population. Selection may be of considerable importance, as shown in a community study where only about half the women with clinically diagnosed migrane had consulted a doctor because of it (Waters and O'Connor, 1970). Details of the families of migraine patients are often obtained in a manner in which bias is almost inevitable. Thus patients may be asked "Does anyone else in your family have migraine headaches similar to yourself?" (Wolff, 1963). Frequently the patient's description of attacks of their relatives is regarded as sufficient and relatives are not questioned about their headaches. Probands with migraine are perhaps more likely to know of affected relatives than are controls. No doubt many are correctly described, but probands may sometimes imagine that relatives are affected when in fact they are not. 